\title{
Poor Attitude to Reading for Pleasure and Its Implications on Acquisition of Language Skills and Academic Achievements: The Case of Students of Secondary Schools in Nigeria
}

\author{
R.C. Ihejirika \\ Director Of General Studies Federal University Of Technology, Owerri
}

\begin{abstract}
The place of reading in the overall intellectual development of man can never be faulted. This is why linguistic scholars have always advocated reading, especially reading for pleasure, in the target language as one of the surest ways of attaining a high level of competence in language skills and excelling in academic achievement. It is based on this background that this paper takes an incisive look at the poor attitude to reading for pleasure as noticed among secondary school students and points out the implications, which among other things include poor communicative competence, poor reading comprehension, lack of creative power, parochial knowledge and poor academic achievement. The paper finally spells out some specific recommendations, which aim at encouraging the students to develop interest in reading for pleasure.
\end{abstract}

\section{Introduction}

Reading is, no doubt, an indispensable exercise in the social and intellectual development and growth of man. This is why emphasis is usually placed on reading in the teaching and learning process. In fact, learning as it concerns formal education, implies reading. However, there are two major forms of reading, namely, intensive and extensive reading. While intensive reading is detailed and careful reading of written material for the purpose of obtaining specific information in one's discipline or profession, extensive reading is the type that we do usually during leisure to familiarize ourselves with a wide variety of reading matter such as newspaper, magazines, fiction, short stories, biographies, autobiographies and many others (Alo, 1997:101)

Reading for pleasure, which is our concern in this paper, falls under the second category above. Reading for pleasure is the same as recreational reading or reading for leisure. Some of the texts that can be read for pleasure are novels, plays and prose passages. Also, newspapers, magazines and texts which deal with our hobbies like animal husbandry and fashion-designing can be read for pleasure. In his own classification of materials that could be read for pleasure, Ahmad (1997:85) listed the following:

1. Literary works

a. $\quad$ Shorts stories novels, tales, thrillers

b. Plays

c. Poems

2. Non-Literary works

a. Daily newspapers, weekly or monthly magazines

b. Biographies and Autobiographies

c. Social commentaries.

In all, one is said to be reading for pleasure when one pre-occupies oneself with reading materials that are outside one's area of specialization.

Research findings point to the fact that reading for pleasure enhances language development, which is very vital in academic achievement. For instance, in a study carried out on the "Effect of Extensive Reading on Second Language learning". Izuagba (1996) concludes that extensive reading through exposure to high interest story books provides a basis for language learning. Also, Alo (1977) states:

Reading of literary texts such as fiction, short stories and poems not only develops one's imagination but also one's vocabulary. A significant benefit that is derived from reading widely is that one acquires new vocabulary items, idioms and figure of speech which are met in context (p. 101).

In addition, reading, especially reading for pleasure, enhances communication competence (Emetaram, 1991; Fagbemi, 1997 and Ihejirika, 2002). This is why Bright and McGregor (1970) are of the opinion that where there is little reading, there will be little language learning. 
Apart from promoting language learning, reading for pleasure broadens one's social horizons and general knowledge. Lending credence to this assertion, Bright McGregor (1970) states that the more the student reads, the more background knowledge he acquires of other ways of life, behaviour and thought. Also, Ahmad (1977) believes that by reading newspapers and weekly magazines, one becomes more informed about the events and social issues of one's country and the world at large.

In view of the foregoing, it is crystal clear that reading for pleasure is an exercise students of all levels of education need most if they must attain an appreciable level of competence in the target language and excel in academic achievement. Unfortunately, however, experience has shown that students, especially those of secondary schools, do not seem to appreciate the place of reading for pleasure in their language development and academic achievement. It is based on this background that this paper aims at reviewing the poor attitude of students of secondary schools to reading for pleasure and pointing out its implications on their acquisition of language skills and academic achievement. The paper will also proffer solutions on how to encourage the students to read for pleasure.

\section{The Problem}

This writer has been privileged to teach the "Use of English" in secondary schools, college of education and university on both full time and part time bases for several years. Within this period, he has had an ample opportunity to interact with the students extensively. His experiences point to the fact that the students are averse to reading for pleasure. At the secondary school level, the situation is quite pitiable in the contemporary times. The proliferation of the so-called home video has not in any way helped matters in this direction. A good number of the students are obsessed with watching films at their homes and video bars to the extent that they hardly have time for reading either intensively or extensively. These days, students are seen exchanging films instead of novels as it was the case in the good old days. In reality, what the students actually do is what could be described as "compulsory reading". That is, reading for test, examination, project write-up or the like only. For them, any reading outside these areas is considered a waste of time. Confirming the student's poor attitude to reading for pleasure, Fagbemi (1977) observes that:

Even students who are supposed to be widely ready may read when the exam is close and for many, the textbooks may be the beginning and end of reading. It is not out of place to find university graduates confessing hardly reading novels for leisure. Even newspapers are like a taboo to some.

These and more go on to reiterate the fact that there is a remarkably low level of reading among Nigerian students which could partly account for the seeming poor academic performance at all levels of education.

Some of the students who seem to be amenable to the preaching that they should cultivate the habit of reading literary texts as a way of improving their academic performance complain that they are discouraged because they cannot afford such literary materials. Again, the nature of the libraries in our secondary schools is nothing to write home about. Regrettably, in some of the schools, the library in its true sense is non-existent. In fact, what is designated library in some schools is mere reading rooms. In the face of this deplorable situation, which characterizes our secondary school environment, the students are handicapped; consequently, no meaningful exercise is carried out in the area of reading for pleasure.

The secondary school curriculum as it is presently conceived does not make adequate provision for reading extensively. For instance, literature, which is expected to expose students to extensive reading, is only made compulsory at the junior secondary school level. At this level, no serious impact is made because of the methodology. It is taught as an integral part of English and as a result much ground is not covered in the area. For the three-year duration of the junior secondary school, the students hardly read more than three novels, three plays and some poems; that is an average of one novel and one play per session. This is grossly inadequate for inculcating in the students the habit of reading extensively.

Besides, at the senior secondary school level, literature is made an elective. Consequently, many students run away from it primarily because of poor foundation and secondly because they are averse to reading for pleasure since there is no encouragement and motivation.

It should also be pointed out that many Nigerian homes are deprived of a conducive environment that encourages reading for pleasure. As a result of high level of illiteracy in Nigeria, especially in the rural areas, many parents do not appreciate the need to provide reading materials at home. In homes where parents are illiterate, it is pretty difficult to have access to newspapers, novels, magazines, etc. Children from such homes are usually deprived and may end up developing a wrong attitude to reading for pleasure. The level of poverty among Nigerians has also been found to be one of the factors responsible for poor reading culture among Nigerians. In the word of Fagbemi (1997:63): 
The poverty level of Nigerians is so high that many can barely afford their children's school fees. Such parents cannot think of buying leisure books for their wards or for themselves, since the thinking would be that such money can be for something more useful to the family.

Although we have pointed out the level of illiteracy and the level of poverty among Nigerians as some factors responsible for the seeming poor reading culture noticed among Nigerians, it is regrettable to note that some literate parents and also affluent ones have not helped matters in any way. Some Nigerian literate parents are so busy chasing material wealth that they hardly have time for reading for pleasure. In such homes, there is no model for the children. Also, some affluent parents may prefer buying expensive materials for their children as a way of displaying their wealth to buying materials the children can read at their leisure.

\section{The Implications On Acquisition Of Language Skills And Academic Achievement}

The poor attitude of the students to reading for pleasure, no doubt, has adverse implications on their acquisition of the language skills, especially reading and writing and academic performance. These implications include:-

1. Lack of Communicative Competence: One of the glaring handicaps that is noticed among contemporary students of secondary schools is their inability to communicate effectively in writing. This deficiency is always manifested in their class assignments and examination scripts. A good number of the students are grossly weak in all aspects of language usage such as choice of words, sentence construction, agreement, spelling, tense, punctuation, etc. This weakness in communicating in writing is inevitable because according to Ihejirika (2002:10-11).

Good knowledge of vocabulary, sentence construction, grammar and punctuation are all it takes to turn out an excellent piece of writing and all these, one can gain through reading.

2. Poor Reading Comprehension: Reading experts have found out that there is a correlation between comprehension and reading speed up to a point; the faster one reads the better one is able to comprehend the thoughts and ideas. For the fact that the students do not practise reading for pleasure, their reading speed will undoubtedly be low which in turn affects their rate of comprehension. In examinations, for instance, cases abound where some of the students could not read simple comprehension passages and answer the questions therein. Also, it is evident that many of the students find it difficult to understand simple written instructions in English. For instance, there have been cases where some students have answered questions more than required in examinations simply because they could not understand the meaning of 'either ... or'

3. Lack of Creative Power: For the fact that many of the students do not read beyond their area of specialization, their creative and imaginative power is usually in doubt. This is so because reading literary materials sharpens one's thinking, imagination and creative ability.

4. Poor Academic Performance: It is obvious that the cumulative effect of all the implications highlighted above is poor academic performance. A student that cannot read and understand, communicate effectively in writing and possess creative ability is most likely to be a poor academic achiever. Thus, the poor academic performance of secondary school students as made manifest in their internal and public examinations such as senior School Certificate Examination (SSCE), University Matriculation Examination (UME), is partly traceable to their poor attitude to reading for pleasure.

5. Parochial Knowledge: These days, it is not unlikely for one to see professionals who are experts in their area of specialization but with limited knowledge of things outside their disciplines. Instances of this nature have compelled some critics to adjudge Nigerian graduates as half-baked, parochial and inefficient. This defect could be partly traced to "compulsory reading" which some students subjected themselves to during their schools days.

\section{Recommendations}

In view of our discussions so far, there is no gain-saying the fact that poor attitude to reading for pleasure among students is one factor that has tremendously impeded their academic achievement. Therefore, to cushion the effect, the following recommendations are inevitable:

1. Extensive Reading should be integrated in the secondary school curriculum and given the status of a core subject. As a core subject, it should be made compulsory at the junior as well as the senior secondary 
school levels. To ensure that Extensive Reading curriculum is effectively implemented, it should be made an examination subject. In addition, departments of English in collaboration with schools/faculties of education in Nigerian colleges of education and universities should design academic programmes that would produce high calibre of NCE and degree reading teachers for secondary schools.

2. The teaching of Literature in English as an integral part of English at the junior secondary school level should also be reviewed. At the JSS level, Literature in English should be taught as a separate subject as it is the case at the SSS. At this level, the teachers should ensure that the students are exposed to several works on different genres of literature.

3. The government should ensure that functional libraries are set up in our secondary schools. The libraries should be well equipped to provide necessary services to the students as well as the teachers. It is also expedient to call on Parent-Teacher Associations (PTA), Old Boys Associations, Non-governmental Organizations (NGO), philanthropists and well-meaning individuals to help in this direction.

4. Teachers as well as literate parents should serve as a model to the students and the children. It is obvious that a blind cannot lead a blind. Therefore, if the student should be convinced that reading for pleasure is worthwhile, the teachers and the parents should lead by example. Teachers should be seen exhibiting a favourable attitude to reading for pleasure while parents should ensure that the children are provided with reading materials at home.

5. The students should be encouraged to form and participate in such clubs as Readers Club, Literary and Debating Society, Creative Writers Association, etc. It is believed that such a forum is capable of influencing positively the reading habit of the students.

6. Teachers and counsellors should not relent on the campaign for the students to cultivate the habit of reading for pleasure. Such campaign could be in form of slogans that should be pasted at strategic points and reechoed in classrooms from time to time.

\section{Conclusion}

It is a statement of fact that Nigerians in general and the secondary school students in particular exhibit poor attitude to reading for pleasure. This weakness, one can argue, is partly responsible for poor reading comprehension, poor communicative competence and ultimately poor academic performance noticed among students. Therefore, our ailing education system with its attendant consequences could partly be addressed by encouraging secondary school students to cultivate the habit of reading for pleasure. To achieve this goal, all hands must be on deck to ensure that the recommendations made in this paper are vigorously pursued and implemented.

\section{References}

[1]. Ahmad, S.B. (1997). Recreational reading. In Helen Chukwuma and Emeka Otagburuagu (eds). English for Academic Purposes. Onitsha: Africana - Fep Publishers Ltd.

[2]. Alo, M.A. (1997). Reading and vocabulary development. In Helen Chukwuma and Emeka Otagburuagu (eds). English for Academic Purposes. Onitsha: Africana - Fep Publishers Ltd.

[3]. Bright, J.A. and G.O. McGregor (1970). Teaching English as a second language. London: Longman Group Ltd.

[4]. Emetaram, U.G. (1991). Functional reading: The information bank for quality education in Nigeria, Literacy and Reading in Nigeria, vol. 5, PP. 229-234.

[5]. Fagbemi, O. (1997). Literacy, the reading culture and national development: Lessons for Nigeria, Literacy and Reading in Nigeria, vol. 7 , p. 65 .

[6]. Ihejirika, R.C. (2002). Strategies for developing communicative skills in the target language with particular focus on science and technology students, Proceedings of the Annual ELTT Conference, vol. 1, pp. 10-14.

[7]. Izuagba, A.C. (1996) The effect of extensive reading on second language learning, Journal of Language and Literatures (JOLL) AICE, Owerri.

[8]. Obafemi Awolowo University (1985). The use of English: A Text, Department of English, Obafemi Awolowo University, Ile-Ife. 